\title{
БІБЛІЙНИЙ ІНТЕРТЕКСТ ПЕРЕКЛАДОЗНАВЧИХ ДОСЛІДЖЕНЬ ІВАНА ФРАНКА
}

\author{
ОКСАНА ДЗЕРА \\ Львівський національний університет імені Івана Франка, Львів - Україна \\ BIBLIJNY INTERTEKST PRZEKŁADOZNAWCZYCH \\ BADAŃ IWANA FRANKI \\ OKSANA DZERA \\ Lwowski Uniwersytet Narodowy im. Iwana Franki, Lwów — Ukraina
}

STRESZCZENIE. Artykuł poświęcony jest analizie przekładoznawczych prac I. Franki, w których omawiane są tłumaczenia Pisma Świętego przez pryzmat krytyki biblijnej. I. Franko opracowuje zasady thumaczenia Biblii w celu analizy naukowej i stosuje je we własnych przekładach.

\section{BIBLICAL INTERTEXT OF TRANSLATION \\ STUDIES RESEARCH BY IVAN FRANKO}

\author{
OKSANA DZERA \\ Ivan Franko National University in Lviv, Lviv - Ukraine
}

ABSTRACT. The article investigates Ivan Franko's Translation Studies research that elucidates the Bible criticism-oriented issues of translating the Holy Scriptures. I. Franko elaborates principles of the Bible translation for the scholarly analysis and realizes them in his own translations.

$\mathrm{Y}$

новітню епоху історії України відбулася суттєва зміна парадигми досліджень праць знакових постатей української культури. Після багатолітнього тиску атеїстичної ідеології привабливими для наукового пошуку виявилися питання релігійно-світоглядних засад творчості та біблійного підгрунтя досліджуваних текстів. Водночас зміщення акцентів часто приводить до абсолютизації ідей щодо обумовленості творчого доробку того чи того автора його християнським світоглядом.

Дослідження творів I. Франка завжди знаходилося в полі пошуку й аналізу їхньої біблійної інтертекстуальності. Навіть літературознавці радянського періоду не могли оминути цю тему, хоча б тому, що наймонументальніші образи, створені його генієм, - це Мойсей і Каїн. Звичайно, акцент ці критики робили на богоборчих мотивах та інтерпретації „не так, як в Біблії” (оцінка, що свого часу звучала для Франка як вирок обивателів, в часи Союзу стала перепусткою в тріаду ключових класиків української літератури).

Перші кроки в рецепції біблійних інтертекстів I. Франка зробили західноукраїнські критики 1920 - 1930-х р.р., зокрема К. Чехович, Д. Козій, Л. Білецький та Г. Костельник. До цієї когорти дослідників долучимо й наддніпрянина П. Филиповича 3 його глибоким аналізом генези Франкової поеми Смерть Каӥна та П. Кудрявцева, який подав перший грунтовний огляд усіх доступних 
йому праць I. Франка з біблійної критики та його літературознавчих досліджень біблійних мотивів у трактаті під назвою Єврейство, євреї та єврейська справа в творах Івана Франка (1929).

У 1950 - 1970-і р.p. вплив Святого Письма на філософсько-релігійний світогляд і поезію І. Франка досліджували західні франкознавці — А. Вільчер (комплексний аналіз актуалізації біблійних мотивів у „до-Мойсеєвий” період творчості поета), К. Біда (біблійні мотиви в наукових творах I. Франка), Л. Шайн (виведення релігійного світогляду І. Франка з його поетичних текстів), О. Домбровський (розгляд Сговістської образності Мойсея) та ін.

У незалежній Україні в дослідницькому полі знаходиться біблійний інтертекст наукових праць І. Франка (Т. Головань, Я. Грицов’ян, Я. Мельник, А. Пашук, В. Погребенник) та його окремих художніх творів (М. Гнатюк, Т. Гундорова, Т. Біленко, І. Бетко, Л. Бондар, М. Ільницький, Н. Захарчук А. Скоць, В. Сулима). Таке розмежування є дещо умовним, оскільки наукова й суто літературознавча сфери досліджень закономірно переплітаються ${ }^{1}$. Як зауважує К. Біда, „ті самі керівні духово-релігійні мотиви просякають обидві (наукову і літературну- О. Д.) галузі Франкової творчості, бо у великій місії, що йому призначено виконати, в його титанічних зусиллях провідника і пророка свого коханого народу він віднайшов суттєві вічні вартості, які віддзеркалюють ідею Бога"2.

Мета цієї розвідки — проаналізувати біблійний інтертекст перекладознавчих досліджень I. Франка. Безсумнівним на сьогодні вважають той факт, що саме I. Франко вперше розробив на теренах України власне перекладознавчий аналіз у його сучасному розумінні. Як зазначає Р. Зорівчак, „шляхом зіставлення перекладу з першотвором та окремих перекладів між собою I. Франко започаткував методику лінгвостилістичного аналізу перекладу, вперше в українській філологічній науці дав науково обгрунтоване розуміння перекладу як єдності літературознавчих, лінгвістичних, лінгвостилістичних, психологічних та естетичних чинників" 3 . Оскільки критика перекладу на той час була ще в зародковому стані, дослідник сам розробив схему перекладознавчого аналізу, насамперед у таких ключових статтях: Каменярі. Украӥнський текст і польський переклад. Дещзо про штуку перекладання, Шевченко по-німецьки і Шевченко в німецькім одязі. Якщо переважна більшість західноукраїнських статей з питань перекладу, що з'являлися в 20-30-і роки, обмежувалася загальними рекомендаціями, I. Франко вже на початку XX ст. вказував на необхідність порівнювати переклад з оригіналом, застосовуючи науковий метод.

Передмова до статті Каменярі охоплює два ключові аспекти перекладознавчого аналізу - історико-літературний (літературознавчий) і естетичний (лінгвостилістичний). Намаганням якнайповніше розкрити перший аспект (соціальні й особисті обставини створення тексту, намір і психологію автора) можна пояснити вибір для аналізу власного оригіналу. Естетичний (лінгвостилістичний аналіз) має рівневу структуру — від віршового розміру до співвідношення частин мови в оригіналі і перекладі.

На необхідність дотримання віршового розміру, типу рими й еквілінеарності автор указує в кількох статтях та рецензіях. Проте адекватність відтворення віршової форми І. Франко вбачає не в іiі наслідуванні, а радше в тій ре-

\footnotetext{
${ }^{1}$ Примітка. Це особливо помітно у дослідженнях Т. Гундарової та Я. Мельник.

${ }^{2}$ К. Біда, Релігійні мотиви в наукових творах Івана Франка, Фенікс (Мюнхен - Детройт) 1956, ч. 7, c. 8.

${ }_{3}$ Р. Зорівчак, Іван Франко як перекладознавець, [в:] Теорія і практика перекладу, Респ. міжвід. наук. зб., вип. 5, Київ 1981, с. 7.
} 
презентації еквівалентності, яку дескриптивіст Дж. Голмс вже в 1970-і означив як аналогічну, коли форма, обрана перекладачем, відповідає оригінальній функціонально. Так, у передмові до власних перекладів Г. Гайне I. Франко зазначає, що замінив оригінальний тонічний вірш чергуванням амфібрахія 3 ямбом, „щоби хоч трохи наблизитися до сього розміру, що надає оповіданню велику свободу і натуральність"4. Цікаво, що інколи І. Франко виправдовує навіть прозові переклади поетичних творів, якщо їхня мета — „передати якомога докладніше сам текст”. Так автор називає „прегарним” неримований переклад Кавказу німецькою, зроблений Каверау ${ }^{5}$. Проте це радше реакція на недоладний, „блідий і для німецького читача майже зовсім незрозумілий” римований німецький переклад Шпойнаровського 6 . Вимогу еквілінеарності перекладу I. Франко теж не зводить до рівня постулату. У передмові до видання Кулішевого перекладу „Гамлета” він зазначає, що мовне багатство Шекспіра і структура англійської мови ускладнюють, а часом унеможливлюють для німецького, а тим більше французького чи слов'янського перекладача, завдання „увібгати один його вірш у свій”७.

Не оминає I. Франко й аналіз фоностилістичних засобів. У статті Шевченко по-німещьки, де розглянуто переклад Ю. Віргінії, названий автор наводить приклади вдалого відтворення мелодійності віршової мови Т. Шевченка, що передусім полягає в пропорційній перевазі голосних над приголосними ${ }^{8}$. Аналіз I. Франка враховує й дрібні, здавалося б, морфологічні нюанси. Так, переведення скали із поеми Каменярі в множину в польському перекладі С. Твердохліба, на думку автора, приводить до того, що „переклад із пластичного робить фантастичне враження”.

Найретельніше порівнює I. Франко образи оригіналу й перекладу. Дослідник підводить до думки, що перекладачі часто не бачать картини, яка змальована словами, або ж змінюють iï на догоду римі. Недоліком перекладу, як випливає з кількох аналізів, може бути надмірна тропеїзація простого і природного вислову (приклади з перекладу С. Твердохліба) або ж сприйняття тропу лише поверхнево (нейтралізація іронії в перекладі Кавказу Шпойнаровським).

Єдиний елемент естетичного аспекту Франкового перекладознавчого аналізу, що не прижився в сучасних дослідженнях, — це поділ слів на дві категоpiї (1 - іменники, дієслова, прикметники; 2 - всі інші) та розгляд співвідношень між цими категоріями в оригіналі та перекладі. Однак ці відсоткові підрахунки, як і завжди в I. Франка, мали не формальну, а функціональну вагу. Слова другої категорії, тобто дискурсивні слова, виконують функцію „тінювання ..., що оживляє і упластичнює картину" ${ }^{\prime 0}$. Саме тому зміна співвідношення в перекладі на користь слів першої категорії веде до „переобтяження віршів змістом, затемнення картин, а подекуди фальшування кольорів" 11 .

${ }^{4}$ I. Я. Франко, Генріх Гейне. Вибір поезій. Переднє слово, [в:] Його ж, Зібр. творів, у 50 томах, Київ $1980-1986$, т. 13, с. 446.

${ }_{5}^{5}$ І. Я. Франко, Поема про сотворення світу, [в:] Його ж, Зібр. творів, у 50 томах, Київ 1980-1986, т. 35 , с. $189-190$.

${ }^{6}$ Там само, с. 192.

7 І. Я. Франко, Передмова [до видання: Уїльям Шекспір. Гамлет, прини датський], [в:] Його ж, Зібр. творів, у 50 томах, Київ 1980-1986, т. 32, с. 169.

${ }^{8}$ І. Я. Франко, Шевченко по-німецьки, [в:] Його ж, Зібр. творів, у 50 томах, Київ 1980-1986, т. 38, с. 529.

${ }^{9}$ І. Я. Франко, Каменярі. Украӥнський текст і польський переклад. Дещо про штуку перекладання, [в:] Його ж, Зібр. творів, у 50 томах, Київ 1980 - 1986, т. 16, с. 14.

${ }^{10}$ Там само, с. 20.

${ }^{11}$ Там само. 
Зразки аналізу перекладів Біблії І. Франко більш чи менш повно подає в працях першого десятиліття XX віку: у студіях з біблійної герменевтики Поема про сотворення світу (1904) та Сучасні досліди над Святим Письмом (1908), критичному огляді рецензії П. Житецького $О$ переводах Евангелия на малоруський язик (1906) і власне перекладознавчому дослідженні Причинок до студій над Острожською Біблією (1907). Матеріалом для аналізу слугують Септуагінта, Острозька Біблія, Пересопницьке Євангеліє, переклади Євангелій П. Морачевського та М. Лободовського і перший повний переклад Святого Письма 1903 р.

Історію церковнослов'янських перекладів Біблії І. Франко стисло викладає в Сучасних дослідах над Святим Письмом і Причинку до студій над Острожською Біблією, зосереджуючись в останній праці на першому повному перекладі Святого Письма церковнослов'янською мовою. Острозьку Біблію як переклад „мертвою" мовою дослідник уважає досить консервативним явищем XVI ст., коли тогочасною українською вже створили „такі неоціненні пам'ятки, як Біблія Скорини 1519 року, як рукописні, доховані до нашого часу популярні переклади Євангелій („Пересопницьке”, Дмитра з Зінькова й ін.) та недокінчений друк Тяпинського”"2.

Власне перекладознавчий аналіз I. Франко зосереджує на Третій Книзі Ездри (за традицією латинської Вульгати - Четверта Книга Ездри). І. Франко обирає саме цю частину Старого Заповіту з двох причин. По-перше, на думку дослідника, високою $є$ ії літературна вартість: „Книга написана з могучим поетичним талантом і подиктована безмежно песимістичним настроєм"13. По-друге, варіант Книги Ездри в Острозькій Біблії - це переклад через цілий ланцюг посередників: ані давньогебрейський оригінал, ані грецький переклад не збереглися, тому острозькі перекладачі використовували текст церковнослов'янського перекладу, зробленого 1499 р. в Новгороді так званою Геннадієвською Біблією, що, відповідно, $є$ перекладом тексту Вульгати. Ретельно зіставляючи переклади XII глави Книги Ездри в Острозькій Біблії, латинському виданні Дж. А. Фабріція (1723), новому німецькому перекладі Гункеля і частково залучаючи сирійський, ефіопський, арабський і вірменський переклади раннього Середньовіччя, I. Франко намагається відтворити первісний сенс утраченого оригіналу й оцінити якість церковнослов'янської версії. Такий перекладознавчий аналіз із елементами порівняльно-історичного підводить дослідника до висновку про недосконалість Острозького перекладу Книги Ездри: „<...> на переклад сеї книги зложили ся дві недотепности: недотепний латинський переклад грецького тексту і недотепний переклад латинського тексту на церковну мову, доконаний механічно, а часто й зовсім недорічно в Новгороді і не поправлений в Острозі" 14 .

Значно більшу увагу приділив I. Франко перекладам Святого Письма українською мовою, виводячи цю традицію від Пересопницького Євангелія. У Поемі про сотворення світу I. Франко чітко окреслює два підходи до перекладу Святого Письма, жоден із яких, на його думку, не реалізований в Біблії П. Куліша, порівн.: „Переклад такої книги, як Біблія, повинен бути або популярний, то значить бодай мовою своєю зрозумілий для широкої маси народу, або науковий, то значить такий, щоб докладно передавав зміст і значення первотвору”"15. Про-

${ }^{12}$ І. Я. Франко, Сучасні досліди над святим письмом, [в:] Його ж, Зібр. творів, у 50 томах, Київ 1980-1986, т. 38, с. 405.

13 I. Франко, Причинок до студій над Острожською Біблією, [в:] Записки НТШ, Львів 1907 , т. 80 , с. 8 .

${ }^{14}$ Там само, с. 18.

15 І. Я. Франко, Поема про сотворення світу, [в:] Його ж, Зібр. творів, у 50 томах, Київ $1980-1986$, т. 35 , с. 275. 
те I. Франко в жодному разі не абсолютизував цей поділ як чітко розмежовану дихотомію. Дослідник наголошує на необхідності збалансувати обидва підходи: „В однім і другім разі треба, аби перекладач сам добре розумів той первовзір, а потім старався передати його іншим так, щоби і вони розуміли його не інакше, як він”" ${ }^{\text {. }}$ Ще ясніше вимоги гармонійного поєднання „науковості” (неухильного дотримання оригіналу) i „популярності” (природності й зрозумілості вихідного тексту) І. Франко окреслює в огляді рецензії П. Житецького на переклад Євангелій М. Лободовським. І. Франко схвально відгукується про критерії оцінювання перекладу, що їх він виділяє в рецензії П. Житецького): наскільки переклад точно передає оригінал (критерій „науковості”); 2) наскільки передає оригінал чистою літературною мовою (критерій „популярності”) ${ }^{17}$. Саме таким критеріям, „вимогам науки і життєвої практики”, на думку I. Франка, відповідає переклад П. Морачевського, який рівняється на Пересопницьке Свангеліє, що його дослідник уважає „взірцем”18. Окремий граматичний аспект перекладу Біблії, на якому зупиняється I. Франко, — це дієприкметникові конструкції активного стану, нехарактерні для української мови. За спостереженням дослідника, П. Морачевський та перекладач Пересопницького Євангелія вміло уникають цих конструкцій. Натомість М. Лободовський і П. Куліш копіюють ї і, як наслідок, „напускають в тексті туману”19.

Негативне ставлення I. Франка до першого повного українського перекладу Святого Письма 1903 р. добре відоме. Заохочення купувати перший український переклад Святого Письма ${ }^{20}$ видається просто жартом на тлі розгромних зауважень. „Шумною реляцією” називає I. Франко окреслену П. Житецьким схему, за якою, на думку останнього, працювали П. Куліш та І. Пулюй: спершу дослівно перекладали з грецької; потім порівнювали із церковнослов'янським, російським, польським, французьким, англійським і латинським перекладами; i, урешті, „доконували остаточної стилістичної редакції’21. I. Франко оскаржує відповідність перекладу 1903 р. і принципу „науковості”, i ,популярності”: „<..> переклад ані передає докладно оригіналу, ані тим менше не передає його чистою мовою"22. Те ж зауваження - у Поемі про сотворення світу: П. Куліш, на думку I. Франка, по-перше, „не знав мов”, а, по-друге, „, ...> пішов підпускати якусь церковщину і дячківщину"23.

Різко критичне ставлення I. Франка до першого повного перекладу Біблії українською вважали несправедливим і його сучасники ${ }^{24}, \mathrm{i}$ дослідники XXI ст. ${ }^{25}$. Зазначимо, що зразки ,дячківщини” в перекладі П. Куліша, що їх наводить I. Франко, витримали перевірку часом й увійшли до загальнолітературного („печалі”) або урочистого чи поетичного мовлення (,рече”, „глаголить”, „воїн-

16 Там само.

${ }^{17}$ І. Я. Франко, П. И. Житеикий. О переводах Евангелия на малоруський язик, [в:] Його ж, Зібр. творів, у 50 томах, Київ 1980 - 1986, т. 37, с. 65.

${ }_{18}$ Там само.

19 Там само, т. 37 , с. 67.

20 Примітка. „<..> отсю книгу (вона дуже дешева) повинна мати кожна читальня і кожний поодинокий чоловік”.

${ }^{21}$ Там само, т. 37, с. 66 .

22 Там само.

${ }^{23}$ І. Я. Франко, Поема про сотворення світу, [в:] Його ж, Зібр. творів, у 50 томах, Київ 1980-1986, т. 35 , с. 276.

${ }^{24}$ К. С тудинський, Листування $i$ зв'язки П. Куліша з Іваном Пулюєм, [в:] П. О. Куліш (матеріяли і розвідки), Львів 1930, ч. II, с. LXXVIII.

${ }_{25}$ М. Стріха, Украйнський художній переклад: між літературою і націєтворенням, Київ 2006, c. 112. 
ство”). До того ж, і сам I. Франко застосовував церковнослов’янізми у власному поетичному мовленні. Першим це зауважив I. Пулюй у відповідь на Франкову критику першого перекладу Біблії ${ }^{26}$. Детальний порівняльний аналіз високої лексики Біблії 1903 р. й лексики із творів I. Франка робить Т. Мороз і доходить висновку, що ,як і в текстах перекладів (Біблії 1903 - О. Д.), так і в мові творів I. Франка використано й збагачено стильовий потенціал церковнослов'янізмів, які засвоїлися в староукраїнській книжній мові, а також в народнорозмовному мовленні"'27.

Зосередимо увагу на Франковому аналізі перекладу перших частин Книги Буття П. Кулішем та в Септуагінті в контексті біблійної критики. Основою Франкового аналізу перекладу П. Куліша в Поемі про сотворення світу є осмислення П'ятикнижжя як рекурсивного і прокурсивного інтертексту ${ }^{28} .3$ огляду на прокурсивну інтертекстуальність I. Франко розглядаючи авторство П'ятикнижжя, стверджує, що його приписування Мойсеєві є помилковим, оскільки воно було створене гебрейськими рабинами й архієреями аж після повернення із вавилонського полону ${ }^{29}$. Думка для Франка не нова: кількома роками раніше він писав про це в Нових дослідах над найдавнішою історією жидів. Проте, якщо в названій праці I. Франко наводить аргументи як апологетиків Старого Заповіту, так і представників „нової біблійної критики”, залишаючи висновки на розсуд читача ${ }^{30}$, то в Поемі категорично заявляє, що визнавати Мойсея автором цих книг „немає підстави”з1. Наведені докази можна поділити на логічний і мовний. Логічною є невідповідність між життям гебреїв у пустелі й законами Мойсея, яких вони мали б дотримуватися: ,_,.>> ні Давид, ні Соломон, ні їхні наступники аж до Вавилонського полону нічого не знають про Мойсеєві книги"з2. Мовний доказ: у П'ятикнижжі (Книзі Левіт) трапляються „домішки арамейщини”, що ввійшли до гебрейської мови після вавилонського полону ${ }^{33}$.

Як рекурсивний інтертекст I. Франко розглядає переказ про створення світу, ілюструючи його власним перекладом у порівнянні з Септуагінтою та перекладом П. Куліша. Уважаємо, що наскрізь інтертекстуальна теза I. Франка Creatio ex nihilo, nihil est ${ }^{34}$ про неможливість творення з нічого, яку вважають визначальною у філософсько-релігійній концепції І. Франка ${ }^{35}$, екстраполюється в його інтерпретації двох перших розділів Книги Буття як на акт світотворе-

26 В. Німчук, Украӥнські переклади Святого Письма, [в:] Das Ukrainische als Kirchensprache (Українська мова в церквах), Wien 2005, b.1, с. 36.

27 Т. Мороз, Спільні риси українського перекладу Біблії 1903 р. та мови творів I. Франка: лексика високого стилю, [в:] „Дослідження з лексикології і граматики української мови”, Зб. наук. праць, Дніпропетровськ 2012, с. 56.

${ }^{28}$ Примітка. Згідно 3 теорією інтертекстуальності, взаємозалежність текстів формується як по висхідній (прокурсивний діалогічний зв’ язок), так і по нисхідній (рекурсивний діалогічний зв'язок), лініях, оскільки джерела тексту існують не лише до його породження, а й після нього.

${ }^{29}$ І. Я. Франко, Поема про сотворення світу, [в:] Його ж, Зібр. творів, у 50 томах, Київ $1980-1986$, т. 35 , с. 272.

${ }^{30}$ I. Я. Франко, Нові досліди над найдавнішою історією жидів, [в:] Його ж, Зібр. творів, у 50 томах, Київ 1980-1986, т. 47, с. 173.

${ }^{31}$ І. Я. Фран ко, Поема про сотворення світу, [в:] Його ж, Зібр. творів, у 50 томах, Київ $1980-1986$, т. 35 , с. 271.

32 Там само, т. 35 , с. 272.

${ }^{33}$ Там само, т. 35 , с. $272-273$.

${ }^{34}$ Примітка. Вперше заявлена в поемі I. Франка Ex nihilo (1885).

35 А. Пашук, Філософський світогляд Івана Франка, Львів 2007, с. 410-411; В. Погребенник, Доктор філософії проти доктора теологї: полеміка довкола „Поеми про сотворення світу” Івана Франка, [в:] „Франкознавчі студії”, зб. наук. праць, Дрогобич 2007, вип. IV, с. 198-199. 
ня, так і на акт текстотворення. Іншими словами, I. Франко аналізує грецький та український переклади найбільш „темних” фраз давньогебрейського оригіналу (мови якого дослідник не знав і користуввся, вочевидь, критичними перекладами та біблійною критикою), щоб вивести старозаповітний переказ про світотворення з тексту вавилоно-ассирійської поеми Енума Еліш (Коли вгорі ...). У центрі аналізу — чотири вирази з гебрейського тексту: rookha, tohuw-a-bohuw, tehowm та ed'. Багатозначне rookha з'являється в перших рядках Старого Заповіту: „А земля була пуста та порожня, і темрява була над безоднею, і Дух Божий (rookha - O. Д.) ширяв над поверхнею води" [Буття: 1:2] ${ }^{36}$. Гебрейське rookha позначає насамперед Дух і вітер, а також життя, передбачення, душа ${ }^{37}$, $n о д u x^{38}$. Утім, ще I. Франко звернув увагу на інший образ, закладений у цей початковий фрагмент Біблії: ужите в гебрейському тексті дієслово rachaph (відповідник ширяв) стосувалося пташки-матері, яка висиджує пташенят. Відтак, як зазначає I. Франко, „той, хто писав ті слова $<\ldots>$, уявляв собі божу Ріх як птицю, що сидить на водах первісного океану (тегом) і вигріває те яйце, з якого мав постати світ" 39 , порівн. велетенський птах $P y x$ (араб. дyx) 3 арабського фольклору або українське яйце-райце, старовинний космогонічний символ, що замикає в собі добро і зло. Звичайно, накладання всіх цих образів $є$ абсолютно неперекладним. І. Франко вважав помилковим дієслово ширяв, що його обирає П. Куліш як відповідник до rachaph, пропонуючи варіант сидів. Більшість дослідників убачають тут образ пташки, яка ширяє над пташенятами, годуючи, зігріваючи і оберігаючи їх ${ }^{40} .41$. Так і Дух Святий покриває своєю любов’ю новонароджений світ. Граматичний жіночий рід rachaph стає основою персоніфікованого образу Духа як матері. Новозаповітній інтертекст є в оповіді про хрещення Ісуса: коли охрещений Ісус виходить із води, з неба спускається Святий Дух у вигляді голубки (гр. Peristera - жін. роду; Свангеліє від Матвія 3:17).

Фактично неперекладною вважає I. Франко фразу, що дослівно звучить „земля була Тогу-ва-богу"42, відкидаючи й тавтологічний переклад П. Куліша (,земля була пуста й пустошня”), і власний дослівний переклад 3 грецької (,земля була видима й невпорядкована”). На думку I. Франка, помилковість інтерпретацій цієї фрази зумовлена девіацією в Септуагінті, що наклала на текст Біблії грецькі міфологічні уявлення: „Греки, наткнувшися на се темне слово, згадали свої національні перекази про початок світу, де говориться, що з самого початку був так званий Хаос — якась безодня, у якій безладно носилися складові частини пізнішого світу"43.

${ }^{36}$ Біблія або Книги Святого Письма Старого і Нового Заповіту, перекл. І. Огієн ка, Київ 2002.

${ }^{37}$ G. M. Lam s a, Idioms in the Bible Explained and a Key to the Original Gospel, London 1985, c.105.

${ }^{38}$ L. Ryken, J. C. Wilhoit, T. Longamn (gen. ed.), Dictionary of Biblical Imagery, InterVarsity Christian Fellowship 1997, c. 1338.

${ }_{39}$ І. Я. Франко, Поема про сотворення світу, [в:] Його ж, Зібр. творів, у 50 томах, Київ 1980-1986, т. 35 , с. 281.

${ }^{40}$ С. Аверинцев, Стилістичні проблеми перекладу Святого Письма, [в:] С. Аверинцев, Софія-Логос. Словник, Київ 2007, с. 93; MatthewHenry’sCommentaryontheWholeBible, [в:] Електронний ресурс; PC Study Bible. New Reference Library, Copyright (c) 1991. (доступ: 22.07.2015).

${ }^{41}$ Примітка. Цей образ есплікується в Передсмертній Мойсеєвій пісні: Господь опікується Своїм народом, Як гніздо своє будить орел, як ширяє він понад своӥми малятами [Повторення Закону 32:11]. Новозаповітня типологія образу світового птаха актуалізується в зверненні Ісуса Христа до народу Єрусалиму: Скільки разів Я хотів зібрати діти твої, як та квочка збирає під крила курчаток своїх, — та ви не захотіли! [Матвій 23:37].

${ }^{42}$ І. Я. Франко, Поема про сотворення світу, [в:] Його ж, Зібр. творів, у 50 томах, Київ 1980-1986, т. 35 , с. 279-280.

${ }^{43}$ Там само, т. 35 , с. 280. 
Загадкове tehowm, що в Септуагінті та в П. Куліша перекладене як безодня (і темрява лежала над безоднею), І. Франко слушно розуміє не як звичайну водяну глибінь, а як „первісний океан, який покривав усю землю"44. Цей первісний tehowm (зазначимо, жіночого роду!) І. Франко услід за теоретиками панвавилонізму ототожнює з Тіамат, водним чудовиськом-Хаосом, що є матір'ю всього сущого. Верховний бог Мардук у двобої вбиває Тіамат, а з іiі тіла творить небо і землю. Таким чином, I. Франко намагається довести, що вавилонська поема Енума Еліш - безпосереднє джерело біблійного тексту про створення світу ${ }^{45}$. Перегуки вавилонського й біблійного оповідань відзначають і сучасні біблієзнавці, уникаючи безапеляційних і категоричних висновків про вторинність старозаповітного тексту.

Наведемо міркування С. Аверинцева: „Можливо, біблійна безодня („Техом") - це спогад про Тіамат, але в такому разі ми повинні відзначити повну деміфологізацію образу. Жодного слова про матір потвор із роззявленою пащею, якою була Тіамат, лише «глибина» або «безодня», або, можливо, «водна хлань», над якою лежить морок, - образ досить таємничий i, якщо завгодно, «міфологічний», але зовсім в іншому значенні цього слова, аніж власне міфологічна фігура вавілонської космогонії" 46.

Ще одне явище, яке, на думку I. Франка, було таким, що існувало до акту світо творення, — це ed', загадкова волога, що вибухла з-під сухої землі ще до того, як Бог створив дощ, і напоїла $\dddot{11}^{47}$. Варіант П. Куліша імла („Виходила імла з землі і напувала всю верховину на суходолі”) І. Франко вважає хибним: по-перше, для поняття імла в гебрейській мові існує інше слово; по-друге, імла не може напоїти землю ${ }^{48}$. Запропонований самим дослідником варіант злива вибухла з землі виправляє лише другу неточність, проте створює нову: злива - це все-таки дощ, якого тоді ще не було створено. Раціоналістичні аргументи I. Франка суперечать його ж позиції, висловленій раніше, — не змішувати раціо із сферою духу ${ }^{49}$.

Різко контрастує з аргументами I. Франка пояснення загадкового явища $е d^{\prime}$ у коментарях до Біблії М. Генрі: Господь створив імлу (mist!) і напоїв нею землю, щоб виявити досконалість влади через дієвість слабких засобів ${ }^{50}$. Типологічна паралель є в образі „тяжкоустого і тяжкоязикого” Мойсея, через якого Господь виголошував свій Закон. У Передсмертній Мойсеєвій пісні (Повторення Закону 32:2), Господня наука тече з уст пророка як роса і як краплі дощу — прозора аналогія на напоєну викликаною Господом імлою землю.

44 Там само.

${ }^{45}$ Там само.

${ }^{46}$ М. Москаленко, 3 , Книги Буття”. Примітки, [в:] На ріках вавилонських. 3 найдавнішої літератури Шумеру, Вавілону, Палестини, Київ 1991, с. 392.

47 Примітка. Інтерпретації ed' в українських перекладах Біблії різняться: імла [Біблія 1903], nара [Біблія Огієнка; Біблія Філарета], волога [Біблія Хоменка] і джерело [Біблія Турконяка], прицьому останній запозичує варіант із Острозької Біблії.

${ }^{48}$ І. Я. Франко, Поема про сотворення свіmy, [в:] Його ж, Зібр. творів, в 50 томах, Київ 1980-1986, т. 35 , с. $288-289$.

49 Примітка. Див. „Це явище, будь-що-будь, незвичайне: < ..> щоб науковий метод, що оперує критично дослідженими і зіставленими фактами, мав служити фундаментом віри, яка грунтується на почутті, натхненні і браку критики” [І. Я. Франко, Die Bibel und die Neueren Entdeckungen in Palästina, in Aegyptin und die Assyrien, von F. Vigouroux Priester von Sain-Sulpici, [в:] Його ж, Зібр. творів, у 50 томах, Київ 1980 - 1986, т. 46, 1, с. 464].

${ }^{50}$ Matthew Henry's Commentary on the Whole Bible, [в:] Електронний ресурc; PC Study Bible. New Reference Library, Copyright (c) 1991 (викор.: 21.06.2015). 
Отже, критичний аналіз перекладу П. Куліша в Поемі про сотворення сві$m y$ обгрунтовує неперекладність „темних” виразів із перших частин книги Буття, зокрема аналізуючи фразу tohuw-a-bohuw, I. Франко зазначає: „Перекладачі та товмачі старалися відгадати його значення і пояснювали його відповідно до своїх здогадів, хоча, по-мойому, ліпше було би попросту лишити се слово без перекладу"

Підсумуємо: І. Франко тлумачить перші розділи Книги Буття як рекурсивний інтертекст: 1) щодо акту світотворення: „Бог застав щось готове”52, тому земля перед створенням світу не „пуста і пустошня” як у П. Куліша і більшості його наступників-перекладачів, а, принаймні, „видима й невпорядкована”; 2) щодо акту текстотворення: джерелом старозаповітної історії про створення світу є вавилонська поема Енума Еліш. Обидві тези Франка оскаржив I. Пулюй, переконуючи, що гебрейський світогляд щодо світотворення стоїть вище від вавилоно-ассирійського, який І. Франко „пхає < ..> в переклад Біблії <..>. Коли вавилонсько-ассирійський світогляд учив, що світ був Мардуком тільки упорядкований, то перва книга Мойсея вчить, що світ був 3 нічого сотворений. Не всесвітній будівничий, що «застав» готові матеріали для будови вселенної $<\ldots>$, а абсолютний Творець сотворив вселенну з нічого! Ось що проповідує єврейська Біблія" 53 . Свідченням незмінності світоглядної позиції І. Франка щодо вторинності Старого Заповіту є його вступ до видання Вавилонські гімни й молитви. Переклади з поясненнями Івана Франка (1911). I. Франко нагадує про те, що Книга Псалмів суттєво вплинула „на сформування того релігійного культу, що на єврейській основі виріс у могутнє дерево християнства, і в перекладі на церковнослов'янську мову мала також значний вплив на сформування душі українського народу", однак він уважає, що вавилоно-ассирійська поезія - „джерело того релігійного духу, який сплодив староєврейське письменство” 54 .

Теоретичну основу Вавилонських гімнів й молитов складають праці німецьких теоретиків пан-вавилонізму — Ф. Гоммеля, Г. Ціммерна та О. Вебера. Історико-літературна розвідка Пісня Дебори, найдавніша пам'ятка старогебрейської поезї побудована на теорії „фрагментів”, згідно з якою П’ятикнижжя складається 3 різночасових документів, зібраних в одну книгу після Вавилонського полону. Подаючи переклад прозової Книги Суддів 4 та поетичної пісні Дебори (Книга Суддів 5), де оповідають про одну й ту ж подію - перемогу Ізраїля над ханаанами, І. Франко доводить, що Пісня Дебори належить до найдавніших зразків гебрейського фольклору.

Власні перекладознавчі принципи, окреслені в працях з біблійної критики, I. Франко втілював у перекладах уривків із Біблії. Окрім гімназійних спроб поетичних переспівів, Франкові переклади Святого Письма не мали самостійного значення, слугуючи ілюстраціями його наукових постулатів ${ }^{55}$. Це переклади: Книги Буття 7-8 у розвідці Потопа світа (1883); окремих уривків із Піс-

${ }^{51}$ І. Я. Франко, Поема про сотворення світу, [в:] Його ж, Зібр. творів, у 50 томах, Київ $1980-1986$, т. 35, c. 280.

${ }^{52}$ Там само, т. 35, с. 279.

${ }_{53}^{53}$ І. Пулюй, Нові і перемінні звізди, Відень 1905, с. 116.

${ }_{54}$ І. Я. Франко, Вавилонські гімни й молитви. Переклади з поясненнями Івана Франка, [в:] Його ж, Зібр. творів, у 50 томах, Київ 1980 - 1986, т. 8, с. 7.

${ }^{55}$ Примітка. Виняток становлять рукописи Франкового римованого й поділеного на строфи переспіву фрагменту Книги Йоіля (ч. 2, вірші 1-11) та перекладу фрагменту з 53 част. Книги Ісайі (вперше опубліковані 2008 р. у статті М. Боднара [М. Боднар, Іван Франко і Біблія: маловідомі й невідомі переклади та переспіви, [в:] Sастит і Біблія в украӥнській літературі, Lub$\operatorname{lin} 2008$, c. $468-471]$. 
ні Пісень у студії Із секретів поетичної творчості (1898); двох перших розділів Книги Буття, уміщених у Поемі про сотворення світу (1905); Тріумфальної пісні Дебори (Книга Суддів 5) у розвідці Пісня Дебори. Найдавніша пам 'ятка давньогебрейської поезї (1912); розповіді про смерть Мойсея із Повторення Закону, а також уривки із Книги Левіт 16:5-10 та Книги Чисел 16 у передмові до другого видання поеми Мойсей (1913); історії Самсона (Книга Суддів 13-16) у статті Леся Українка (1898) та студії-передмові до власного перекладу поеми Дж. Мільтона Самсон-борець (1913); епізодів про зачаття Ізмаїла і пророцтво щодо народження Ісаака (Книга Буття 16, 17:15-22, 18:1-15) та розповідей про народження Самсона (Книга Суддів 8:1-24) і Самуїла (Перша Книга Самуїлова 1-2) у студії Благовіщення. Порівняльний дослід біблійної теми. 3 додатком благовіщенської драми Івана Дамаскина в віршованім перекладі на изерковнослов'янську мову (1914). Франкові переклади Нового Заповіту (кількох фрагментів Свангелія від Матвія, Свангелія від Луки та Дій святих Апостолів) містить розвідка Молитва за ворогів (1911) та Про євангельські основи поеми T. Г. Шевченка “Марія” (1914). Хоч на час написання вищезгаданих студій існував повний переклад Святого Письма, I. Франко волів послуговуватися власним, зробленим за посередництвом критичного французького перекладу Е. Райса.

Було б помилковим списати причину, через яку I. Франко завдавав собі труду перекладати вже перекладене задля ілюстративної мети, виключно на негативне сприйняття Кулішевого перекладу. І. Франко потребував перекладу наукового, що, за його критерієм, дорівнює ретельному підряднику. Таке розуміння перекладу для потреб герменевтичного чи літературознавчого аналізу формулює I. Франко в рецензії на розвідку I. Борусовського Мефістофель в Гетевім „,Фаусті” і Люччифер в Байроновім „Каїні”. Проба їх еволюиії і характеристики (1907). Попри позитивне враження від студії I. Франка обурює, що І. Борусовський використав для аналізу Фауста першу версію його перекладу поеми Гете і докорив йому „за недоладну передачу деяких місць”. „Хто ж його силував користуватися перекладом, коли для наукового оброблення надається єдине оригінал або його точний прозовий переклад”, - коментує I. Франко й додає: „Так поважні вчені не роблять "56. Він обгрунтовує ідеї перекладами, що відповідають принципу дослівності.

56 І. Я. Франко, Мефістофель в Гетевім „,Фаусті” $і$ Люичиер в Байроновім „Каӥні”. Проба їх еволюияї і характеристики, [в:] Його ж, Зібр. творів, у 50 томах, Київ 1980 - 1986, т. 37 , c. 275 . 